\title{
0.G.Solovyeva
}

\section{Treatment of complicated flu and acute respiratory viral infections with antiviral drug Ingavirin}

\begin{abstract}
Summary
Features of clinical course of viral and viral-and-bacterial pneumonias in patients with influenza or other acute respiratory viral infections (ARVI) admitted to a pneumology department of a municipal hospital during the season from November, 2009, to February, 2010, have been analyzed in this study. Thirty seven patients ( 25 females, 12 males, the mean age, $38.1 \pm 10.2$ yrs) were examined. Of them, 12 patients were infected with a highly virulent influenza A / H1N1 / pdm09 virus. The efficacy of antiviral therapy with Ingavirin as a part of treatment of complicated influenza and ARVI has been discussed in this article.

Key words: highly virulent influenza A / H1N1 / pdm09 virus, viral-and-bacterial pneumonia, Ingavirin.
\end{abstract}

\section{Резюме}

Проанализированы особенности клинического течения вирусных и вирусно-бактериальных пневмоний у больных ОРВИ и гриппом, госпитализированных в пульмонологическое отделение МУЗ "Нефтеюганская городская больница" (Ханты-Мансийский автономный округ-Югра), в эпидсезон с ноября 2009 по февраль 2010 г. Были обследованы 37 пациентов (25 женщин и 12 мужчин, средний возраст $38,1 \pm 10,2$ года), из них 12 - с высокопатогенным гриппом A / H1N1 / pdm09. Представлена эффективность противовирусной терапии препаратом Ингавирин ${ }^{\circledR}$ в комплексном лечении осложненных форм гриппа и ОРВИ.

Ключевые слова: высокопатогенный грипп А / H1N1 / pdm09, вирусно-бактериальная пневмония, Ингавирин ${ }^{\circledR}$

Широкая распространенность острых респираторных вирусных инфекций (ОРВИ) является глобальной медицинской, социальной и экономической проблемой во всем мире [1]. Воздушно-капельный механизм передачи обусловливает их повсеместное распространение и высокую интенсивность эпидемического процесса. Эта группа инфекций наносит значительный ущерб здоровью населения и экономике стран. ОРВИ отличаются полиэтиологичностью инфекционных агентов, поражающих респираторный тракт. Возбудителями респираторных вирусных инфекций являются вирусы гриппа А, B, $\mathrm{C}$, парагриппа, аденовирусы, риновирусы, респираторно-синцитиальный вирус и др. [2].

Вирусы гриппа А, обладая высокой степенью изменчивости генома, способны продуцировать реассортанты с новыми антигенными и биологическими свойствами. Такие штаммы, попадая в неиммунную человеческую популяцию, вызывают пандемии с периодичностью 1 раз в 10-40 лет, с быстрым охватом до трети населения планеты. 2009-2010 гг. были объявлены Всемирной организацией здравоохранения (BO3) периодом пандемии гриппа. Первая пандемия гриппа в XXI в. этиологически связана с вариантом вируса A / H1N1 / pdm09, являющегося реассортантом 2 генотипов вирусов гриппа А свиного происхождения. Грипп, вызванный пандемическим вирусом, имел ряд существенных эпидемиологических и клинических отличий от сезонного. Основная за- болеваемость регистрировалась среди людей молодого и среднего возраста. Вирус оказался способен инфицировать нижние дыхательные пути и вызывать быстро прогрессирующую первичную или вирусную пневмонию и острый респираторный дистресс-синдром (ОРДС), которые являются наиболее тяжелыми осложнениями пандемического гриппа и нередко заканчиваются летальным исходом [1, 3, 4].

В Российской Федерации превышение эпидемического порога по гриппу и ОРВИ за неделю с 16 по 22 ноября 2009 г. было зафиксировано на территории 76 субъектов. На территории Ханты-Мансийского автономного округа (ХМАО) - Югра в эпидсезон 2009-2010 гг. с респираторными симптомами за медицинской помощью обратились 238966 человек (в основном школьники и дети дошкольного возраста от 3 до 6 лет). Удельный вес заболевших от численности населения автономного округа составил $15,3 \%$, количество госпитализированных - 3300 человек. 296 случаев заболевания ОРВИ закончились осложнениями в виде вирусной, вирусно-бактериальной пневмонии. Пик заболеваемости гриппом зафиксирован в 47-ю нед. 2009 г., когда за медицинской помощью обратились 28977 человек. С октября 2009 по 23 июля 2010 г. на территории ХМАО было зарегистрировано 73 случая лабораторно подтвержденного гриппа A / H1N1 / pdm09, из них 15 в г. Нефтеюганске. Наиболее пораженной группой являлось взрослое население в возрасте 18-40 лет 
(3,2 случая на 100 тыс. населения). В этой возрастной группе заболели 48 человек, что составило $74 \%$ от числа заболевших. Смертельные случаи зарегистрированы в городах Сургуте (4), Мегионе (2), Нефтеюганске (2) и Сургутском районе (2).

Стратегия лечения гриппа и ОРВИ подразумевает обязательное назначение противовирусной терапии [5]. Ингибиторы нейраминидазы (осельтамивир и занамивир) - эффективные противовирусные препараты, рекомендованные ВОЗ для лечения пандемического гриппа. Однако научные и клинические исследования, проводимые в России [1, 6, 7], продемонстрировали противовирусную активность в отношении вируса гриппа А / H1N1 / pdm09 отечественного препарата Ингавирин ${ }^{\circledR}$, сопоставимую по клинической эффективности с осельтамивиром и превосходящую эффективность арбидола.

Целью настоящей работы стала оценка клинической эффективности и безопасности Ингавирина ${ }^{\circledR}$ в составе комплексной терапии пациентов с гриппом и ОРВИ, осложненными вирусной или вируснобактериальной пневмонией.

\section{Материалы и методы}

Под наблюдением находились пациенты, госпитализированные в пульмонологическое отделение МУЗ Нефтеюганской городской больницы в период с ноября 2009 по февраль 2010 г., с лабораторно подтвержденным диагнозом грипп или ОРВИ, осложненные вирусной или вирусно-бактериальной пневмонией среднетяжелого и тяжелого течения. Беременные женщины, лица моложе 18 и старше 60 лет в группу наблюдения не включались.

С целью подтверждения вирусной инфекции и верификации этиологических агентов исследовались образцы назальных смывов и мазков из зева пациентов методом полимеразной цепной реакции (ПЦР). Всем пациентам проводили рентгенологическое исследование органов грудной полости, измеряли сатурацию кислорода методом пульсоксиметрии. При наличии дыхательной недостаточности (ДН) (тахипное > 25 дыханий в минуту, цианоз, показатель $\left.\mathrm{SpO}_{2}<94 \%\right)$ проводился забор артериальной крови из лучевой артерии для исследования газового состава. Лабораторные методы исследования включали в себя клинический и биохимический анализ крови, бактериологическое исследование мокроты. Температура тела измерялась ежедневно 2 раза в сутки, в 7:00 и 19:00. Динамику симптомов интоксикации и катаральных симптомов, физикальных данных, показателей пульсоксиметрии фиксировали через каждые 6 ч.

\section{Результаты и обсуждение}

В исследование были включены 37 пациентов (25 женщин и 12 мужчин) в возрасте от 19 до 58 лет (средний возраст $-38,1 \pm 10,2$ года). Все пациенты (с их слов) не были вакцинированы против сезонного гриппа.

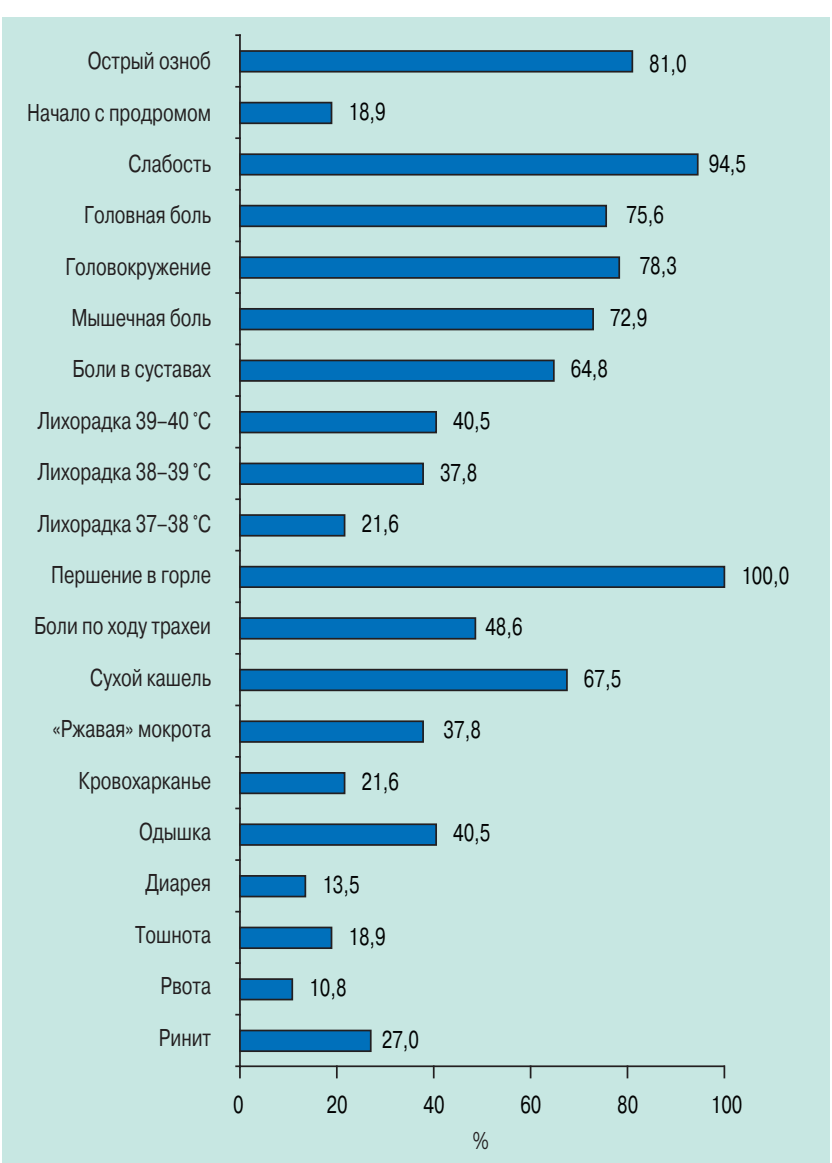

Рис. 1. Клинические симптомы гриппа и ОРВИ

На догоспитальном этапе 29 человек $(78,4$ \%) получали противовирусную терапию, из них 21 $(72,4 \%)$ - арбидол в течение 5-7 дней, 5 (17,3\%) ремантадин, 3 (10,3\%) - кагоцел. 8 (21,6\%) больных получали антибактериальную терапию (амоксициллин, аугментин, сумамед, ципрофлоксацин). Все пациенты принимали жаропонижаюшие средства. Длительность заболевания до госпитализации составила 3 суток у 5 (13,5 \%), 4 суток - у 4 (10,8\%), $\geq 5$ суток - у 28 (75,7 \%) человек. 67,5\% пациентов имели избыточный вес с индексом массы тела (ИМТ) $>31 \mathrm{KГ} / \mathrm{M}^{2}$.

В составе комплексного лечения больные получали кислородотерапию, антибактериальные препараты (респираторные фторхинолоны, цефалоспорины III-IV поколения, макролиды), отхаркивающие и гормональные средства, бронхолитики, инфузионную терапию, в качестве противовирусного химиопрепарата - Ингавирин ${ }^{\circledR}, 90$ мг, в течение 5 дней.

У всех наблюдаемых при поступлении в стационар в легких выслушивалось жесткое дыхание, у 27 $(72,9 \%)-$ крепитация.

Клиническая картина гриппа и ОРВИ характеризовалась типичными симптомами (рис. 1).

Наиболее тяжелое и быстро прогрессирующее течение заболевания отмечалось у 12 пациентов с гриппом A / H1N1 / pdm09 [8-10]. Ухудшение состояния начиналось с озноба и последующего присоединения лихорадки в первые 24 ч: температура тела 39$40{ }^{\circ} \mathrm{C}$ отмечена у 7 , фебрильная $\left(38-39{ }^{\circ} \mathrm{C}\right)$ - у 3 , субфебрильная $\left(37-38^{\circ} \mathrm{C}\right)$ - у 2 пациентов. Показатель 
температуры тела при поступлении в стационар в среднем по группе составил $37,8 \pm 0,5{ }^{\circ} \mathrm{C}$. У 12 больных гриппом A / H1N1 / pdm09 - 38,8 $\pm 0,7{ }^{\circ} \mathrm{C}$. C первых суток преобладали симптомы интоксикации - пациенты жаловались на резкую слабость, выраженную головную и мышечную боль, ломоту в суставах, головокружение. У 4 человек появились симптомы дисфункции кишечника: жидкий стул без патологических примесей до 10 раз в сутки, тошнота и рвота. На 2-3-и сутки присоединялись катаральные симптомы - боли по ходу трахеи и сухой кашель, першение в горле. Через 4-6 дней после развития характерных симптомов гриппа у 10 пациентов появилась одышка и акроцианоз с падением уровня $\mathrm{SpO}_{2}$ от 84 до $93 \%$ (среднее значение $-89,5 \pm$ $3,1 \%)$, ДН [11, 12]; у 8 из них - на 6-8-е сутки присоединилось кровохарканье (5) и кашель с мокротой ржавого цвета (3).

По данным рентгенологического исследования органов грудной полости, 2-стороннее усиление сосудисто-интерстициального компонента визуализировалось в 37,9 \% случаев, в остальных случаях - 2-стороннее понижение пневматизации и инфильтрация в базальных отделах легких. У 10 пациентов с пневмонией, ассоциированной с вирусом гриппа А / H1N1 / pdm09, рентгенологическая картина и компьютернотомографические изменения характеризовались признаками острого респираторного дистресс-синдрома (ОРДС) - диффузные мультифокальные инфильтраты, картина "матового стекла" и нарастающего интерстициального отека легких [12-14].
Вирусологическое исследование назальных смывов и мазков из зева методом ПЦР показало следующее: грипп А / H1N1 / pdm09 верифицирован у 12 (32\%), сезонный грипп А и В - у 18 (49\%), ОРВИ не гриппозной этиологии - у 7 (19\%) пациентов.

По данным бактериологического исследования мокроты, у большинства больных микрофлора была представлена Streptococcus pneumoniae.

Вирусно-бактериальная пневмония диагностирована в 70,3 \% случаев (26 пациентов), вирусная в $29,7 \%$ (11 больных).

У 75 \% пациентов с гриппом А / H1N1 / pdm09 в анализах крови наблюдалась лейкопения (минимальное количество лейкоцитов составляло 1,5-2,6 × 109 / л), в отличие от пациентов с сезонным гриппом и ОРВИ, у которых в основном преобладал лейкоцитоз. Кроме этого, наблюдалось повышение скорости оседания эритроцитов (СОЭ) $>30$ мм / ч, умеренный подъем печеночных ферментов: аланинаминотрансферазы (АЛТ) и аспартатаминотрансферазы (АСТ).

При использовании Ингавирина ${ }^{\circledR}$ в комплексной терапии вирусассоциированной пневмонии продолжительность периода лихорадки составила 24-72 ч (в среднем по группе $-49 \pm 18,7$ ч).

Продолжительность симптомов интоксикации слабости, головной и мышечной боли, головокружения - составила $6,4 \pm 2,1,2,09 \pm 0,94,2,0 \pm 0,66$ и $3,6 \pm 1,17$ суток соответственно. Продолжительность кашля в среднем была 9,25 \pm 2,45 суток, боль по ходу трахеи при кашле сохранялась в среднем
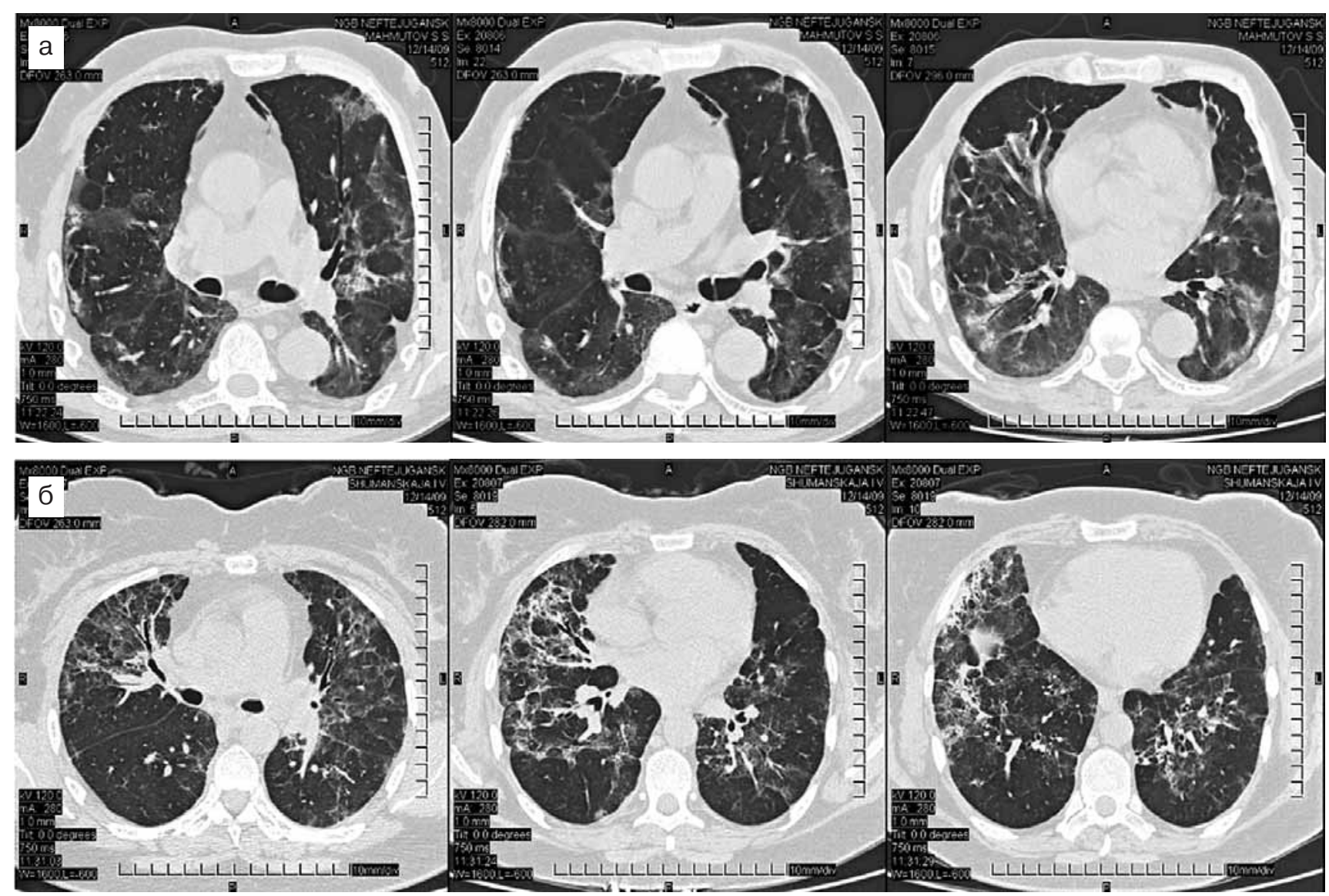

Рис. 2. Компьютерные томограммы грудной клетки пациентов М. (а) и Ш. (б), в динамике лечения 
$8,33 \pm 2,18$ суток. У пациентов с гриппом А / H1N1 / pdm09 уменьшение одышки наблюдалось на 5-11-е сутки (в среднем одышка сохранялась 7,3 $\pm 2,05$ суток). Нормализация сатурации кислорода отмечалась на 3-11-е сутки (без кислородотерапии), кровохарканье и кашель с отделением "ржавой" мокроты исчезали к концу 3-4-х суток, диарея и рвота сохранялись в течение $1-2$ суток.

Аускультативные признаки пневмонии в виде крепитации сохранялись от 5 до 10 суток (в среднем $-6,5 \pm 1,44$ суток).

Рентгенологические проявления разрешающейся пневмонии сохранялись более длительно, чем клинические симптомы. В динамике лечения наблюдалось уменьшение в размерах фокусов инфильтрации, на их месте визуализировались участки повышенной плотности легочной ткани и сетчатости рисунка, вследствие интерстициального легочного фиброза (рис. 2a, б).

Ингавирин ${ }^{\circledR}$ хорошо переносился пациентами. Нежелательные явления и побочные эффекты отсутствовали. Все пациенты были выписаны в удовлетворительном состоянии.

\section{Клинический пример № 1}

Пациентка Б. 1967 года рождения, госпитализирована в пульмонологическое отделение 13.11.2009 с жалобами на повышение температуры тела до $40,1^{\circ} \mathrm{C}$, слабость, сухой кашель, першение в горле, ломоту в суставах, головную боль. Ухудшение самочувствия - с 7.11.2009, когда появился озноб, затем присоединились вышеперечисленные симптомы. По рекомендации участкового терапевта, в течение 5 дней принимала арбидол.

При объективном обследовании: вес -88 кг, рост - 158 см (ИМТ - 35,2 кг / м²). Кожные покровы бледные, сухие. Инъекция сосудов склер, легкая субиктеричность. Слизистая ротоглотки гиперемирована. Аускультативно дыхание жесткое, крепитация в нижних отделах, частота дыхания - 16 в минуту. Тоны сердца ясные, тахикардия - до 100 в минуту. Артериальное давление (АД) 100 / 60 мм рт. ст. Печень не увеличена.

По данным рентгенологического исследования органов грудной клетки от 13.11.2009: на уровне нижних полей обоих легких визуализируются очагово-инфильтративные тени на фоне усиленного легочного рисунка. Корни малоструктурны (рис. 3а).

Общий анализ крови от 13.11.2009: лейкопения - до 2,6 × 109/л (палояко-ядерные лейкоциты - 25), СОЭ - 35 мм / ч.

Биохимический анализ крови: АЛТ - 160,1 U / 1, АСТ - 94,3 $\mathrm{U} / \mathrm{1}$, билирубин - в пределах нормальных значений.

С 15.11.2009 появились жалобы на одышку, затрудненное дыхание (тахипное - до 24 в минуту, акроцианоз, тахикардия - до 127 в минуту, $\mathrm{SpO}_{2}-90,7 \%$, АД - 85 / 60 мм рт. ст.), кашель с мокротой ржавого цвета - в небольшом количестве. Анализ газового состава артериальной крови от 16.11.2009 свидетельствовал о прогрессировании дыхательной недостаточности: $\mathrm{pH}-7,41$, $\mathrm{PaO}_{2}-63$ мм рт. ст., $\mathrm{PaCO}_{2}-36$ мм рт. ст. Вирусологическое ис- следование назального смыва и мазка из зева от 15.12.2009 подтвердило инфицирование вирусом гриппа А / H1N1 / pdm09.

Клинический диагноз: высокопатогенный грипп А / H1N1 / pdm09, осложненный вирусно-бактериальной пневмонией тяжелого течения. Прогноз по шкале PORT соответствует средней степени риска (96 баллов, класс риска IV).

Пациентка получала Ингавирин ${ }^{\circledR}$ в составе комплексной терапии с 16.11.2009 в дозе 90 мг 2 раза в сутки первые 2 дня, затем 90 мг в сутки последующие 3 дня, т. к. в случаях тяжелой или ухудшающейся болезни ВО3 рекомендовано применение более высоких доз противовирусных препаратов в любые сроки заболевания и в течение более длительного периода времени (ВО3. Рекомендации по применению противовирусных препаратов. Пандемический грипп (H1N1) - 2009. Краткое сообщение № 8. 21 августа 2009 г., Женева).

К концу 2-х суток противовирусной терапии температура тела нормализовалась. На 3-й день $\mathrm{SpO}_{2}$ составила $95 \%$ без кислородотерапии, уменьшились симптомы интоксикации. Кашель и боли по ходу трахеи сохранялись в течение 5 суток, мокрота "ржавого" цвета исчезла через 3 суток, показатель уровня лейкоцитов в крови достиг нормальных значений в эти же сроки.

Пациентка выписана через 14 суток с положительной клинической, лабораторной (нормализация биохимических показателей крови) и рентгенологической динамикой (локальные изменения в легких по типу интерстициального легочного фиброза, рис. 3б) на амбулаторное наблюдение.

\section{Клинический пример № 2}

Пациентка К. 1961 года рождения заболела остро 8.11.2009, когда появился озноб, мышечные боли, головная боль, першение в горле, повышение температуры до $39,1{ }^{\circ} \mathrm{C}$, слабость. Амбулаторно принимала арбидол в течение 5 дней. С 10.11.2009 появился жидкий стул до 8 раз в сутки без патологических примесей, тошнота, рвота, сухой кашель, одышка. 13.11.2009 госпитализирована в пульмонологическое отделение.

Объективно: вес - 100 кг, рост - 170 см (ИМТ - 34,6 кг / м²). Кожные покровы бледные, сухие. Гиперемия конъюнктив, слизистой ротоглотки. Аускультативно в легких дыхание жесткое, 2-сторонняя крепитация в нижних отделах, ЧДД - 17 в минуту. Тоны сердца приглушены, тахикардия - до 110 в минуту, АД - 90 / 60 мм рт. ст. Живот мягкий, чувствительный по ходу кишечника. Через 2 суток присоединились одышка, признаки нарастающей ДН: акроцианоз, тахипное - до 22 в минуту, $\mathrm{SpO}_{2}-92 \%$. 16.11.2009 появилось кровохарканье.

Анализ газового состава артериальной крови от 16.11.2009 свидетельствовал о респираторном алкалозе вследствие гипервентиляции: $\mathrm{pH}-7,47, \mathrm{PaO}_{2}-62,1$ мм рт. ст., $\mathrm{PaCO}_{2}-29,1$ мм рт. ст., $\mathrm{SpO}_{2}-90,3 \%$.

Рентгенологическое исследование органов грудной клетки: 2-стороннее интенсивное усиление легочного рисунка, инфильтрация, преимущественно в нижних отделах, и участки "матового стекла", характерные для начала интерстициального отека легких (рис. 4a).

ПЦР от 17.11.2009: вирус гриппа А / Н1N1 / pdm09 идентифицирован в материале мазков из зева и назального смыва.

Клинический диагноз: высокопатогенный грипп А / H1N1 / pdm09, осложненный вирусно-бактериальной пневмонией тяжелого течения. Прогноз по шкале PORT соответствует низкой степени риска (83 балла, класс риска III).

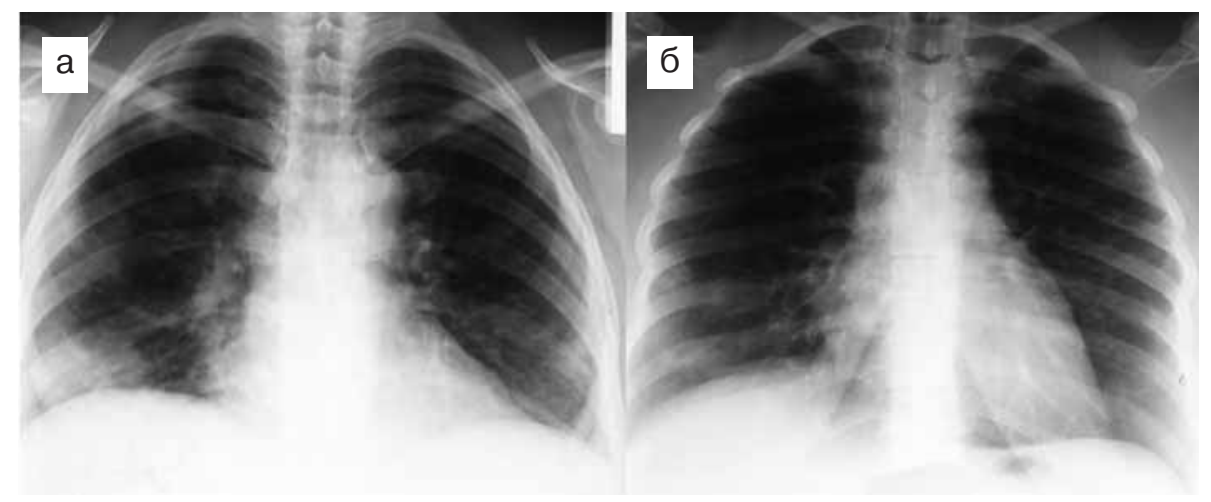

Рис. 3. Рентгенограммы органов грудной клетки пациентки Б. 42 лет: а - до лечения; б - после лечения (описание в тексте) 

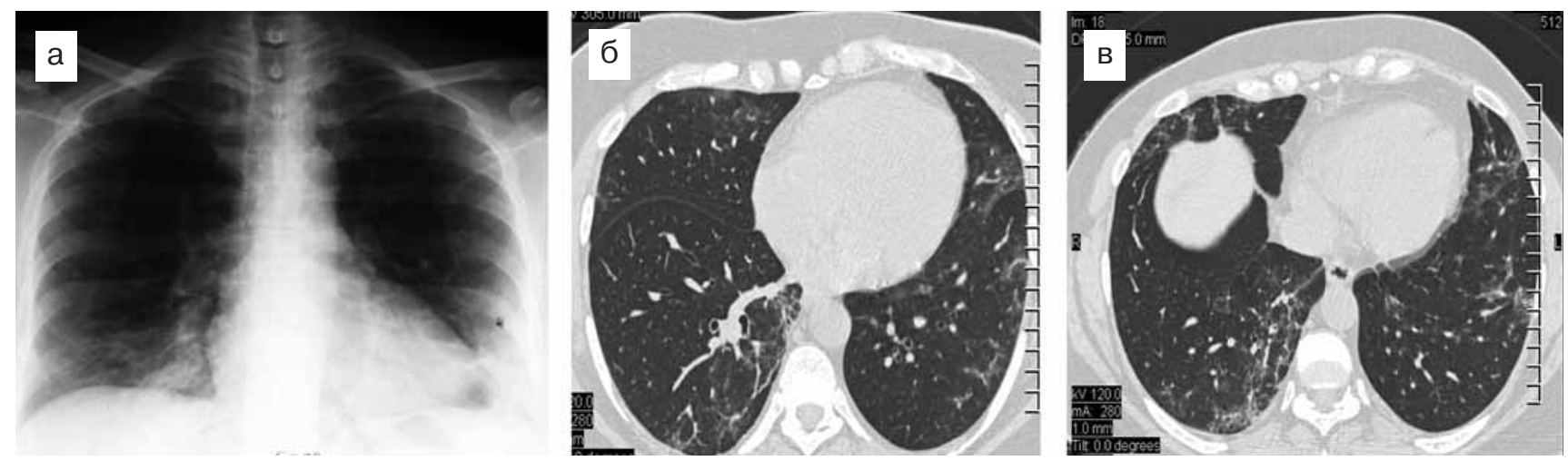

Рис. 4. Рентгенограмма (а) и компьютерные томограммы (б, в) пациентки К. 48 лет

Лечение: Ингавирин ${ }^{\circledR}$ в составе комплексной терапии с 16.11.2009 в дозе 90 мг 2 раза в сутки первые 2 дня, затем 90 мг в сутки последующие 3 дня.

В первые 24 ч противовирусной терапии значительно уменьшились симптомы интоксикации (слабость, головная и мышечная боль). Нормализация температуры тела наблюдалась через 36 ч. Через 2 суток прекратилось кровохарканье и диспепсические явления (диарея и рвота). Кашель с мокротой "ржавого" цвета сохранялся 3 дня, боли по ходу трахеи и одышка - в течение 7 суток. По данным пульсоксиметрии, через 72 ч после начала приема Ингавирина ${ }^{\circledR}$ в составе комплексной терапии показатель $\mathrm{SpO}_{2}$ составлял $96 \%$ без кислородотерапии.

Рентгенологические проявления разрешающейся пневмонии сохранялись более длительно, чем клинические симптомы (по данным литературы этот период составляет от 2 до 4 нед., а в некоторых случаях - до 6 нед.)

Через 4 нед. после начала заболевания, по данным компьютерной томографии органов грудной клетки, на уровне средних и нижних полей визуализировался интерстициальный фиброз легких после перенесенной вирусно-бактериальной пневмонии (рис. 4б, в)

Пациентка выписана через 21 день с положительной клинической и рентгенологической динамикой на амбулаторное наблюдение.

\section{Заключение}

Назначение противовирусной терапии госпитализированным больным с осложненным течением гриппа даже в поздние сроки болезни позволяет снизить риск летальных исходов.

Ингавирин ${ }^{\circledR}$ - эффективный и безопасный противовирусный препарат для комплексного лечения вирусных и вирусно-бактериальных пневмоний, осложнивших грипп и ОРВИ (в т. ч. пандемический A / H1N1 / pdm09), о чем свидетельствует непродолжительный период лихорадки, купирование симптомов интоксикации и катаральных симптомов в короткие сроки.

\section{Литература}

1. Шубин И.В., Райчева М.В., Баштовой М.А., Чучалин А.Г. Современные подходы к диагностике и лечению гриппа в пандемический период. Воен.-мед. журн. 2010; 4: $27-32$.

2. Щелканов М.Ю., Колобухина Л.В. Грипп, его формы и осложнения. Новая аптека: аптеч. ассортимент 2012; 1 : $8-11$.

3. Львов Д.К., Бурцева Е.И., Щелканов М.Ю. и др. Распространение нового пандемического вируса гриппа А (H1N1) v в России. Вопр. вирусол. 2010; 55 (3): 4-9.
4. Орлова С.Н., Шибачева Н.Н., Довгалюк Т.И. и др. Особенности современного течения ОРВИ / гриппа в условиях эпидемического подъема и эффективность противовирусной терапии у пациентов с гриппом A / H1N1 / sw. Эпидемиол. и инфекц. бол. 2010; 5: 51-54.

5. Авдеев С.Н. Тяжелые формы пандемического гриппа А / H1N1 / 2009. Атмосфера. Пульмонол. и аллергол. 2010; 4: 2-10.

6. Колобухина Л.В., Меркулова Л.Н., Щелканов М.Ю. и др. Первый опыт применения препарата Ингавирин при лечении больных гриппом, вызванным новым пандемическим вирусом A / H1N1 / swl. Consilium Medicum 2009; 11 (11): 3-6. Репринт.

7. Логинова С.Я., Борисевич С.В., Щукина В.Н. и др. Изучение противовирусной активности Ингавирина в отношении возбудителя "мексиканского" пандемического гриппа A / H1N1 / 2009 in vitro и in vivo. Антибиотики и химиотер. 2010; 11-12: 17-21.

8. Лузина Е.В., Ларева Н.В., Гончарова М.А. Клиникопатологоанатомические сопоставления при гриппе А (H1N1). Клин. мед. 2011; 4: 64-44.

9. Ruuskanen O., Lahti E., Jennings L.C. et al. Viral pneumonia. Lancet 2011; 377 (9773): 1264-1275.

10. Riquelme R., Torres A., Rioseco M.L. et al. Influenza pneumonia: a comparison between seasonal influenza virus and the H1N1 pandemic. Eur. Respir. J. 2011; 38: 106-111.

11. Perez-Padilla R., de la Rosa-Zamboni D., Ponce de Leon S. et al. Pneumonia and respiratory failure from swine-origin influenza A (H1N1) in Mexico. N. Engl. J. Med. 2009; 361: 680-689.

12. Luyt C.É., Combes A., Trouillet J.L. et al. Virus-induced acute respiratory distress syndrome: epidemiology, management and outcome. Presse Med. 2011; 40 (12, Pt 2): e561-e568.

13. Проскурина М.Ф., Юдин А.Л., Афанасьева Н.И. и др. Рентгенографические и компьютерно-томографические изменения, выявляемые при тяжелой форме гриппа A (H1N1) (свиного происхождения). Мед. визуализ. 2011; 4: 21-27.

14. Marchiori E., Zanetti G., Hochhegger B., Mano C.M. Highresolution $C T$ findings in a patient with influenza $A(\mathrm{H} 1 \mathrm{~N} 1)$ virus-associated pneumonia. Br. J. Radiol. 2010; 83: 85-87.

\section{Информация об авторе}

Соловьева Ольга Георгиевна - к. М. н., врач-пульмонолог пульмонологического отделения МУЗ "Нефтеюганская городская больница", гБОУ ВПО "Тюменская государственная медицинская академия"; тел.: (3452) 20-30-93, (3463) 23-63-57; e-mail: solog.fedor@mail.ru 